\title{
Impact of Front Line Demonstration on Yield and Economics of Sweetcorn Variety (Madhuri)
}

\author{
Kabita Mishra* and Debasis Sarangi \\ Krishi Vigyan Kendra, Ganjam-II, Odisha, India \\ *Corresponding author
}

\section{A B S T R A C T}

\section{Ke y w o r ds \\ Sweetcorn, Front line demonstration, Green cob yield, $\mathrm{B}: \mathrm{C}$ ratio, \\ Article Info \\ Accepted: \\ 18 October 2018 \\ Available Online: \\ 10 November 2018}

The present study was conducted by Krishi Vigyan Kendra, Ganjam-II during 2015 and 2016 in rabi in three villages Khalingi, Jura, Sunathara. The KVK scientists have conducted frontline demonstration in sweetcorn with the active participation of farmers with the objective to demonstrate the improved technologies in crop. The improved technologies consisting use of improved variety (Madhuri), Integrated nutrient and weed management, pest and disease management. The results of demonstration showed that farmers could increase the sweetcorn productivity notably by switching over to improved variety and adoption of improved production technology. From the front line demonstration, it was observed that the sweetcorn variety Madhuri recorded higher green cob yield (83.3q/ha) as compared to farmers practice $(65.7) q /$ ha. The increase in the demonstration yield over farmer's practices was 26.9 per cent. The technology gap and technology index were $11.7 \mathrm{q} / \mathrm{ha}$ and 12.3 respectively.

\section{Introduction}

Maize is prominent cereal crop of world. "Queen of cereal crops maize" is the third most important food crops after rice and wheat in India. Maize (Zea mays L.) is the only New World cereal of commercial significance. According to advance estimate it is cultivated over 9.23 million ha (Annual Report, IIMR New Delhi, 2015) with 24.17 million tonnes production having an average productivity of $2560 \mathrm{~kg} \mathrm{ha}^{-1}$, contributing nearly 9 percent in national food basket. India stands on fifth in global maize production, contributing to $2.4 \%$ of world production about $5 \%$ share in world harvested area. However, the country lags far behind in productivity - 24.1 quintal/ha against world average of 51.4 quintal/ha.

This cereal is referred to as Miracle Crop and Queen of the Cereals due to its high productivity potential compared to other crops of Gramineae or poaceae family members. It is a seasonal crop, and annually, it can be harvested thrice, i.e., in kharif, rabi and summer seasons. Maize is usually grown as a sole crop; in some instances, it can be grown as an intercrop with different crop combinations like Sugarcane, Cotton, Vegetables, Legume crops etc 
It is an important staple food for human beings, comprises a significant animal and poultry feed besides enormous industrial importance and various uses. Green cobs of maize, backed in fire or steam boiled form a favorite dish of the urbanites. But, the hybrid and composite varieties presently available in the market are neither sweet nor have succulency.

Many types of maize are used for food, sometimes classified as various subspecies related to the amount of starch, content like flour corn- Zea mays var. amylacea, popcornZea mays var. everta, dent corn- Zea mays var. indentata, flint corn- Zea mays var. indurata, sweet corn- Zea mays var. saccharata and Zea mays var. rugosa, waxy corn- Zea mays var. ceratina, pod corn Zea mays var. tunicata, striped Maize- Zea mays var. japonica. Among all the types of maize, sweet corn (Zea mays saccharata) is one of commercial used maize type.

Sweet corn (Zea mays L. Saccharata) grown successfully for vegetable purpose in countries like USA, Canada, Thailand, Taiwan, Indonesia, and Sri Lanka. In India, its cultivation is popular in Haryana, Maharashtra, Meghalaya, Karnataka, and Andhra Pradesh. It is a new economic product of maize having higher sugar content in green cobs (14-20\%), more delicious and it has thinner pericarp (seed coat) than normal corn, making it tender for diversification and value addition of maize as well as the growth of the food processing industry.

The demand for sweet corn in the amusement park, theaters, circus and exhibitions is increasing with increasing urban population. It contains Energy of $90 \mathrm{kcal}$, Carbohydrates-19 g, Sugar-3.2 g, Dietary fiber-2.7 g, Fat-1.2 g, Protein-3.2 g, Vitamin A-10 $\mu \mathrm{g}$, Folate (Vit.B9)-46 $\mu \mathrm{g}$, Vitamin C-7 mg, Iron-0.5 mg, Magnesium-37 mg and Potassium270 mg nutritional value per $100 \mathrm{~g}$ sweet corn seed (USDA Nutrient database).

For diversification and getting more valuable crops, presently greater emphasis is being given on cultivation of sweet corn to augment the income for farming community dwelling in the outskirts of big cities and metropolis. It has been developed into a multi-dollar business because of its potential as a value added product for export and a good food substitute. It has potentiality not only in domestic market but also in an international market. Traditionally, maize has been widely cultivated as a rainfed crop during kharif season in the country. But recent studies have shown that it can also be successfully grown during rabi season in many parts of the country. The yield level of maize during rabi season is considerably higher than that of kharif due to its higher water and fertilizer use efficiencies and comparatively more favorable conditions. Cultivation of rabi maize is also gaining popularity among the farmers of India. The lack of knowledge about the use and economic importance of sweet corn and unavailability of appropriate production technologies are the major constrains for its popularization among Indian maize growers.

To enhance the production and income per unit area it is very essential to grow high value short duration crops like sweet corn which not only increase awareness about this crop but also meet requirement. The sweet corn being a short duration crop; it is best suited in existing cropping systems after kharif rice. Being a highly remunerative crop it gives higher returns as compared to either Indian bean or chickpea. Of good quality fodder for their milch animal which will result in an increased milk production and thus increase the income of farmers. Sweet corn is a hybridized variety of maize specifically bred to increase the sugar content. 
It varies from normal corn essentially for genes that affects starch synthesis in seed endosperm and elevates the level of polysaccharides and decrease the starch content. Thus the kernels of sweet corn are creamy and tastes much sweeter than normal corn especially at 18-21 days after pollination. The total sugar content in sweetcorn ranges from 25-30 per cent.

By conduction of front line demonstration on farmer's field there was significant increase in knowledge level of the farmer and majority of farmer's showed high level of satisfaction about demonstrated technologies (Raj et al., 2014).

Keeping in view such problems and after detailed survey the KVK, Ganjam-II made an attempt with an objective to substitute existing maize variety with a new promising sweetcorn variety Madhuri. Therefore, it was considered important to evaluate the impact of front line demonstration on yield and economics of sweetcorn for its suitability in the existing farming situation for higher productivity and income. FLD was effective in changing the attitude, skill and knowledge of improved / recommended practices of high yielding variety including adoption.

The productivity of maize per unit area and time could be increased by adopting feasible scientific and sustainable management practices with a suitable variety. Taking into account the above consideration, frontline demonstrations were carried out in a systematic manner on farmers ${ }^{\text {ee }}$ field to show the worth of a new variety and convincing farmers about potentialities of improved production management practices of maize for further adoption (Dhaka et al., 2010).

\section{Nutritive value of sweet corn in human diet}

Sweet corn provides carbohydrates and potassium: 1 ear contains 70 kilocalories energy; $250 \mathrm{ml}$ ( 1 cup) kernels contain 148 kilocalories energy in body. A half cup serving contains folic acid and small amounts of magnesium, phosphorus, and thiamine. It is also good source of vitamin ' $C$ ' and ' $A$ '.

\section{Materials and Methods}

Krishi Vigyan Kendra, Ganjam-II conducted front line demonstration (FLD) on sweet corn var Madhuri at the farmer's field of Khalingi, Jura and Sunathara of Ganjam district during Rabi season of 2015-16 and 2016-17. The soil of demonstration plots ranged from medium black to sandy loam. The district of Ganjam lies in two agro climatic zones i.e East \& South Eastern coastal plain zone and North Eastern Ghat Zone of Odisha extending from $18^{0} 13^{\prime} \mathrm{N}$ to $19^{0} 10^{\prime}$ North latitude to $82^{0} 5^{\prime}$ to $83^{\circ} 23^{\prime}$ 'East longitude. The Average Normal Rainfall of this district is $1276.2 \mathrm{~mm}$ and more than $75 \%$ of the precipitation is received over five months i.e. June- October. Agriculture is the primary occupation of inhabitants of this district. The maximum and minimum temperature of this district is $39^{\circ} \mathrm{C}$ and $18.9^{\circ} \mathrm{C}$ respectively. The various aspects included in the FLD were introduction of high value new crops (sweet corn), variety (Madhuri), integrated nutrient management, weed management, proper irrigation schedule, integrated pest management and harvesting. The detail guidance regarding scientific cultivation practices of sweet corn were given to the farmers to increase the awareness of improved technology and to increase productivity of sweet corn through conducting training programmes by KVK Scientists.. The crop was sown during second fortnight of November in both the years. In demonstrations plots, seeds were treated with the bio- fertilizers like azotobacter and phosphate solublizing bacteria before sowing and application of chemical fertilizer @ 120:60:60 kg N:P:K/ha was done. The yield data was recorded from demonstrated as well as control (Farmers' practice) fields. 
In improved package of practices, good quality seed, recommended balanced fertilizer, line sowing and timely sowing, effective plant protection and chemical and manual weed management and frequent monitoring the farmer's field during cropping season. Yield data were collected from farmer's practices and improved practices. Cost of cultivation, gross return, net return and benefit cost ratio (B: $\mathrm{C}$ ratio) were computed and analysed. Final crop yield(green cob and green fodder yield) were recorded and the gross return were calculated on the basis of prevailing market price of the produce. For the introduction of the technology, different extension approaches through regular field visit and interpersonal communication were made by the scientists of Krishi Vigyan Kendra, Ganjam-II. Trainings on farmers and farm women were conducted for the awarness among the farmers and field days were conducted for the horizontal spread of technology. Also leaflets and pamphlets on improved package of practices on sweet corn cultivation were distributed among the farmers in the villages. Further the technology gap, extension gap and technology index were calculated using the following formula as given by Samui et al., (2000).

Technology index $=$ Potential Yield Demonstration Yield/ Potential Yield x 100

Technology gap $=$ Potential Yield Demonstration Yield

Extension gap $=$ Demonstration yield - Yield under Farmers Practices

B: $\mathrm{C}$ ratio $=$ Net income $($ Rs. $/$ ha $) /$ cost of cultivation (Rs. / ha)

$\%$ increased over farmers practices = Improved practices - Farmers practices / farmers practices x 100

Tabular analysis involving simple statistical tools like mean was done by standard formula to analyze the data and draw conclusions and implications.

\section{Details of technology}

Sweet corn variety "Madhuri" differs from dent corn by one recessive gene "su" on forth chromosome which prevents the conversion of part of sugars in to starch. It has been reported to be a mutant from field corn. "Madhuri" a sweet corn variety first of its kind in the country was released from Maize Research Station, Amberpet, Hyderabad. It is a composite sweet corn variety being medium plant type and matures in about 95 days. The seeds are wrinkled. It contains about $9 \%$ total sugars in dried seed while up to $33 \%$ on milky or fresh grain basis Keeping all these in view the variety Madhuri has been recommended for cultivation in Odisha.

\section{Technology transferred}

For varietal introduction, different extension approaches were made. Interested farmers were supplied with Sweetcorn variety Madhuri by KVK, Ganjam-II. The sweetcorn variety could successfully out yield all other local and hybrid maize varieties and recorded eye catching higher yield. During Rabi 2016, the area under sweetcorn Madhuri expanded horizontally to 40 hectares from a mere 1 hectare during first year (2015) of introduction and adopted by 65 farmers in 11 villages. Due to efforts of $\mathrm{KVK}$, scientists field visit, interpersonal communication and individual efforts of the farmers, the sweetcorn variety Madhuri could spread to 30 hectares of the district.

\section{Results and Discussion}

\section{Yield}

Results of front line demonstrations conducted during Rabi 2015 and 2016 in farmers field of 
three villages indicated that the sweet corn variety Madhuri recorded higher cob yield $83.3 \mathrm{q} / \mathrm{ha}$ which is 26.9 per cent higher yield than local check(65.7q/ha). It performed better in demonstration plots owing to best management practices like integrated nutrient management, weed management, irrigation and pest management practices. Thus the FLD might have a positive impact on farming community in the district over local check. Similar yield enhancement in different crops in front line demonstration has been documented by Poonia and Pithia (2011), Patel et al., (2013) and Raj et al., (2013). Yield of the front line demonstration trials and potential yield of the crop was compared to estimate the yield gaps which were further categorized into technology and extension gaps (Hiremath and Nagaraju, 2009). The data regarding performance of sweet corn in front line demonstrations presented in Table 1 .

\section{Extension gap}

The extension gap is the difference or gap between demonstration yield and farmers practices (control). Higher extension gap 18 $\mathrm{q} / \mathrm{ha}$ was found during 2015 and lower $17.2 \mathrm{q} / \mathrm{ha}$ was in 2016. This extension gap should be assigned to adoption of improved transfer technology in demonstrations practices resulted in higher seed yield than traditional farmer practices. This emphasized the need to educate the farmers through various means for more adoption of improved high yielding varieties and newly improved agricultural technologies to bridge the wide extension gap. More use of new high yielding varieties by the farmers will subsequently change this alarming trend of galloping extension gap. The new technologies will eventually lead to the farmers to discontinuance of old varieties with the new technology.

Table.1 Productivity, technology gap, Extension gap and technology Index in sweet corn variety Madhuri under front line demonstration

\begin{tabular}{|c|c|c|c|c|c|c|c|}
\hline \multirow[t]{2}{*}{ Year } & \multicolumn{3}{|c|}{ Yield(q/ha) } & \multirow{2}{*}{$\begin{array}{l}\% \text { of local } \\
\text { check }\end{array}$} & \multirow{2}{*}{$\begin{array}{l}\text { technology } \\
\operatorname{gap}(\mathbf{q} / \mathbf{h a})\end{array}$} & \multirow{2}{*}{$\begin{array}{l}\text { extension } \\
\operatorname{gap}(q / h a)\end{array}$} & \multirow{2}{*}{$\begin{array}{l}\text { technology } \\
\text { imdex }(\%)\end{array}$} \\
\hline & potential & $\begin{array}{l}\text { improved } \\
\text { technology }\end{array}$ & $\begin{array}{l}\text { local } \\
\text { check }\end{array}$ & & & & \\
\hline 2015 & 95.0 & 80.3 & 62.3 & 28.9 & 14.7 & 18 & 15.47 \\
\hline 2016 & 95.0 & 86.3 & 69.1 & 24.9 & 8.7 & 17.2 & 9.15 \\
\hline MEAN & 95.0 & 83.3 & 65.7 & 26.9 & 11.7 & 17.6 & 12.3 \\
\hline
\end{tabular}

Table.2 Economics of sweet corn variety Madhuri under front line demonstration

\begin{tabular}{|c|c|c|c|c|c|c|c|c|c|c|}
\hline \multirow[t]{2}{*}{ Year } & \multicolumn{2}{|c|}{$\begin{array}{c}\text { green cob } \\
\text { yield } \\
\text { (q/ha) }\end{array}$} & \multicolumn{2}{|c|}{$\begin{array}{c}\text { cost of } \\
\text { cultivation( }(\mathrm{Rs} / \mathrm{ha})\end{array}$} & \multicolumn{2}{|c|}{$\begin{array}{c}\text { gross } \\
\text { return(rs/ha) }\end{array}$} & \multicolumn{2}{|c|}{$\begin{array}{c}\text { net } \\
\text { return(rs/ha) }\end{array}$} & \multicolumn{2}{|c|}{ B:C ratio } \\
\hline & DP & FP & DP & FP & DP & FP & DP & FP & DP & FP \\
\hline 2015 & 80.3 & 62.3 & 28533 & 21300 & 83860 & 64400 & 55327 & 43100 & 2.94 & 1.49 \\
\hline 2016 & 86.3 & 69.1 & 30241 & 25322 & 89860 & 71600 & 59619 & 46278 & 2.97 & 1.54 \\
\hline Mean & 83.3 & 65.7 & 29387 & 23311 & 86860 & 68000 & 57473 & 44689 & 2.95 & 1.51 \\
\hline
\end{tabular}



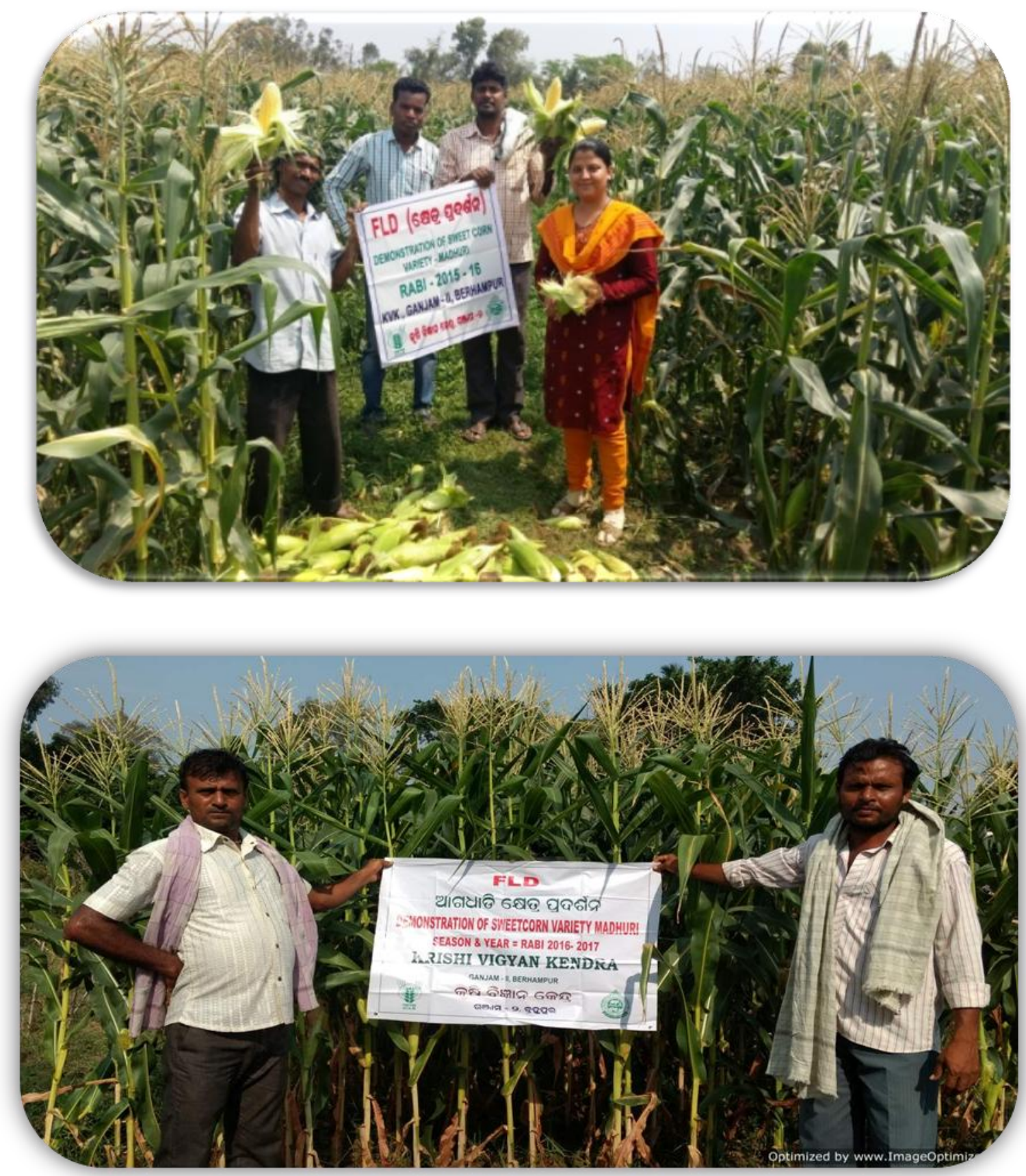

\section{Technology gap}

The technology gap is the difference or gap between the demonstration yield and potential yield. The demonstrations in both the years recorded the technology gap of $14.7 \mathrm{q} / \mathrm{ha}$ during 2015 which was $8.7 \mathrm{q} / \mathrm{ha}$ which was higher than that during 2016. The technology gap observed may be attributed to dissimilarity in the soil fertility status and weather conditions (Mandavkar et al., 2012).

\section{Technology index}

The Technology index shows the feasibility of the technology at the farmer's field. The lower the value of technology index more is the feasibility. The technology index was 
reduced from 15.47 to 9.15 per cent during 2015 to 2016? (Table 1) which shows the higher feasibility of the demonstrated technology.

\section{Economics of front line demonstration}

The economics of sweetcorn production under front line demonstrations have been presented in Table 2. The results of economic analysis of green gram production revealed that cost of cultivation increased in demonstration practice (Rs29387/ha) as compared to Farmers practice plot check (Rs23311/ha). It was observed that front line demonstrations recorded higher gross returns (Rs86860/ha) and net returns (Rs57473/ha) whereas in farmers practice the gross returns (Rs68000 /ha) and net returns (Rs44689 /ha). The benefit cost ratio of demonstration plot (2.95) was also more than the farmers practice (1.51).

The study concluded that the FLD programme is an effective tool for increasing the production and productivity of sweetcorn and changing the knowledge, attitude and skill of the farmers. This has not only resulted in socio-economic security but also helped in attaining food and nutrition security to the community along with fodder requirement of farm animal. This will subsequently increase the income as well as the livelihood of the farming community. The per cent increment in yield of sweetcorn to the extent of 26.9 in demonstration over the farmers practice created greater awareness and motivated the other farmers to adopt the improved package of practices of sweetcorn. This demonstration built the relationship and confidence between farmers and KVK scientists.

\section{Acknowledgement}

The author is thankful to the ATARI, ZoneVII, Jabalpur (ICAR) for providing financial assistance towards conducting this front line demonstration.

\section{References}

Annual Report, ICAR 2015-16. Indian Institute of Maize Research, New Delhi India.

Dhaka, B.L.; Meena, B.S. and R. L. Suwalka, (2010). Popularization of Improved Maize Production Technology through Frontline Demonstrations in Southeastern Rajasthan J Agri Sci, 1(1): 39 42.

Hiremath S M and Nagaraju M V 2009. Evaluation of front line demonstration trials on onion in Haveri district of Karnataka, Karnataka J Agric Sci 22 (5):1092-1093

Patel, H.R., Patel, F.H., Maheriya, V.D and Dodia, I.N 2013. Response of Kharif green gram (Vigna radiata L) to Sulphur and Phosphorus with and without biofertilizer application. Bioscan, 8(1):149-152.

Poonia TC and Pithia MS 2011. Impact of front line demonstrations of chickpea in Gujarat, Legume Research, 34(4): 304307

Raj AD, Yadav V, Rathod JH. Impact of front line demonstrations (FLD) on the yield of pulses. Internat. J Scient. \& Res. Public. 2013; 3(9):1-4.

Samui, S.K., Maitra, S., Roy, D.K., Mondal, A.K. and Saha, D. 2000. Evaluation of front line demonstration on groundnut (Arachis hypogea L.) in Sundarbans, Journal of Indian Society of Coastal Agriculture Resources, 18(2): 180-18

Shah K A, B M Tandel, C K Timbodiya and Nital N Patel (2013): Introduction of sweetcorn $\mathrm{Cv}$ Sugar \&\% through frontline demonstration in tribal area of Navsari District In Gujarat. J Krishi Vigyan, 2(1):84-85.

Suthar M., D Singh, V Nepolian and AK Singh (2014): Performance of sweetcorn (Zea mays L) varieties under varying fertility levels. Indian J Agron., 59: 168-170.yan, 2(1) 
Mandavkar, P.M., Sawant, P.A., and Mahadik, 2012, Evaluation of Front line demonstration trial on rice in Raigad district of Maharastra. Rajstan Journal of Extension Education, 20:4-6.

\section{How to cite this article:}

Kabita Mishra and Debasis Sarangi. 2018. Impact of Front Line Demonstration on Yield and Economics of Sweetcorn Variety (Madhuri). Int.J.Curr.Microbiol.App.Sci. 7(11): 2597-2604. doi: https://doi.org/10.20546/ijcmas.2018.711.296 